\title{
Redaksioneel
}

\section{'n Hervormde perspektief: Die kerkvereniging van $1885^{*}$}

\author{
DJC van Wyk
}

Op 7 Desember 1885 het die Nederduitsch Hervormde of Gereformeerde Kerk in die Zuid-Afrikaansche Republiek tot stand gekom. Hierdie nuwe kerk was die produk van die vereniging tussen die Nederduitsch Gereformeerde Kerk en die Nederduitsch Hervormde Kerk en dit sou vir baie jare in die omgang bekend staan as die 'Verenigde Kerk'. In 1892 het die kerkvereniging finaal tot niet gegaan. Die wortel van die mislukking lê in die stelling wat die Hervormde Konsulentsgemeente van Pretoria, Witfontein (Bronkhorstspruit) op 13 Februarie 1886 gemaak het: 'Van deze kerk onzer vaderen willen wij geen afstand doen...' Gedurende 14-16 Februarie 1986 het die Nederduitsch Hervormde Kerk van Afrika die honderdjarige voortbestaan van die Hervormde Kerk, 'n Hervormde erfenis en 'n Hervormde teologie feestelik herdenk. In die onderhawige aflewering van die Hervormde Teologiese Studies is enkele artikels opgeneem wat die aandag op die mislukte kerkvereniging en die voortbestaan van 'n Hervormde teologie in Suid-Afrika vestig. Die sekretaris van die redaksie, dr DJC van Wyk, bied vervolgens ' $n$ Hervormde perspektief op die 1885-1886kerkvereniging. Die artikel is met 'n paar wysigings uit die tydskrif $D e$ Kat oorgeneem.

\section{DIE POSISIE VAN WAARUIT ONS KYK EN PRAAT}

Ons praat vanuit die hoek van die Nederduitsch Hervormde Kerk. Dit is ' $n$ Kerk wat in die proses van kerkvereniging van 1885 seergekry het, en nog altyd letsels daarvan oorgehou het. Miskien is dit deel van die oorsaak dat die Hervormde Kerk soms as spelbreker gesien word wat kerkvereniging op koppige wyse verydel.

Vir baie mense is dit vreemd dat die Hervormde Kerk praat van 'n

\footnotetext{
- Oorgeneem, met erkentlikheid, uit De Kat (Des 1985/]an 1986), Jrg 1 Nr 6, bl 41-43, met enkele wysigings.
} 
fees om die gebeure van 100 jaar gelede te herdenk. Ander praat van 'n verleentheid of kerkisme. Hoe vier 'n mens 'n kerkvereniging wat misluk het? So word gevra. Die Kerk het egter duidelik gesê dat hy met sy fees die klem wil laat val op die positiewe: dankbaarheid oor die voortbestaan van 'n Hervormde Kerk, Hervormde teologie en Hervormde erfenis na 1885. Gedurende hierdie eeu het die Kerk 'n eie Bybels-gefundeerde nuanse in verband met kerkeenheid ontwikkel. Aan 'n geforseerde, organisatoriese kerkeenheid het hy niks. Terselfdertyd spreek hy hom uit teen 'n vlug in 'n blote geestelike of onsigbare eenheid van die kerk. Die eenheid van die kerk is basies 'n geloofseenheid. Dié eenheid in Christus bestaan ongeag alle uiterlike verdeeldheid. Maar die geloof sonder die werke is dood. Dit geld ook vir die eenheid van die kerk. Daarom: Die eenheid in geloof, in Christus, moet sigbaar, moet dade word in die lewe en gesindheid van die lidmate van die kerk.

Die Nederduitsch Hervormde Kerk se feestelike herdenking van die gebeure van 'n eeu gelede beteken dus nie dat hy hom op kerkistiese wyse verlekker in 'n eeu se kerklike verdeeldheid nie. Om al die wonde van 'n eeu gelede weer oop te krap, ag hy sinloos. Aan 'n onverkwiklike woordestryd oor die kerkgeskiedenis het hy niks. Maar dit beteken nie dat die lesse van die geskiedenis vergeet mag word nie. En die kerkvereniging van 1885-1886 het ons 'n paar dinge geleer....

\section{DIE GEBEURE VAN 100 JAAR GELEDE}

Die kwessie van toenadering tussen die Ned Geref en Hervormde Kerke het die eerste keer amptelik ter sprake gekom op 'n Algemene Kerkvergadering van die Ned Geref Kerk in 1877. Daar is gevra dat die Sinode van die Kaapse Ned Geref Kerk 'n kommissie na Transvaal moes stuur om die Nederduitsch Hervormde Kerk om toenadering te pols. Hoewel die voorstel nie so aanvaar is nie, was dit deels die aanleiding daartoe dat ds HS Bosman tydens die Algemene Kerkvergadering van die Hervormde Kerk in 1879 die saak van kerkvereniging ter sprake gebring het. Hy deel hier mee dat die Ned Geref Kerk ook die saak as wenslik beskou. Die Hervormde Algemene Vergadering spreek hom daarna in ' $n$ besluit positief oor kerkvereniging uit. Dit sou so aan die Ned Geref Kerk oorgedra word en verdere toenadering sou afgewag word.

Die saak is daarna deur die Eerste Vryheidsoorlog vertraag. Eers in November 1881 sou albei kerke se Algemene Kerkvergaderings kom- 
missies benoem om verder aan die saak aandag te gee. As vrug van hierdie kommissies se werk het die eerste Algemene Kerkvergadering van die Nederduitsch Hervormde of Gereformeerde Kerk op 7 Desember 1885 vergader.

Op 13 Februarie 1886 het die Konsulentsgemeente van Pretoria, Witfontein (later Bronkhorstspruit), onder leiding van die kerkraad soos volg besluit:

'De vergadering dezer gemeente tot bespreking harer geestelijke belangen, verklaart zich onder geene omstandigheden aan een dwangbesluit te onderwerpen ... Gevoelt ons integendeel tevreden te blijven hetgeen wij was en nu nog ben, namelijk: Ned. Herv. ... Van dezer kerk onzer vaderen willen wij geen afstand doen...'

Hierdie ingrypende besluit het beteken dat die Nederduitsch Hervormde Kerk sou bly voortbestaan. Terselfdertyd was dit die begin van die verbrokkeling van die poging om te verenig.

\section{WAAROM HET DIT MISLUK?}

Daar moet inderdaad van 'n mislukking gepraat word. Want vanjaar, 'n eeu later, bestaan die Nederduitsch Hervormde en Nederduitse Gereformeerde Kerk nog albei selfstandig. Die Hervormde Kerk het in die proses onberekenbare skade gely, nie net aan eiendom nie, maar ook aan lidmate en predikante. In 1886 moes van die grond af begin word. Vir die Hervormde Kerk het die verenigingspoging geen positiewe gevolge gehad nie. Al vrugte wat hy gepluk het, was bitterheid, twis en 'n onverkwiklike stryd om deur middel van hofsake iets van wat syne was, te red. Kan dié Kerk verkwalik word as hy finaal sê dat hy hom in dié soort kerkvereniging nooit weer sal laat inpraat nie?

Waarom het die kerkvereniging misluk?

- Die kerkvolk is nie geken nie. Die saak is deur die twee Algemene Kerkvergaderings geïnisieer, deurgedryf en afgehandel. Behalwe dat dit takties verkeerd was, het die vergaderings volgens kerkreg ultra vires gehandel. Daarom kon die besluite om te verenig die toets in die wêreldse hof nie deurstaan nie.

Daar word vandag dikwels verkeerdelik beweer dat dit die teoloë is wat die kerke uiteenhou. Daar word te oppervlakkig beweer dat die lidmate ryp is om te verenig. In 1885 is dit ook aanvaar en het geblyk' $n$ fatale vergissing te wees. 
- Die motivering vir kerkvereniging was nie kerklik-teologies nie, maar polities. Die Eerste Vryheidsoorlog het 'n sterk vlaag van eenheid en nasionalisme ontketen. Die vraag was: Kan eenheid op kerklike terrein nie dieselfde positiewe gevolge as op die nasionale terrein hê nie?

- Omdat die motivering polities van aard was, is kerklik-teologiese verskille genereer. Met verstommende oppervlakkigheid is oor alle kerklike en teologiese verskille heen gehardloop en gemaak asof dit nie bestaan nie. Dieselfde fout word vandag weer gemaak as so oppervlakkig en simplisties beweer word dat daar tog eintlik nie verskille tussen die kerke is nie. Intussen het die huidige gesprek van die Tussenkerklike Kommissie diepliggende verskille ten opsigte van Skrifbeskouing, Skrifgesag en Kerkbegrip na vore gedwing.

- Meerderwaardigheid teenoor mekaar en gebrek aan respek vir mekaar. Solank dit so is, is die ware bedoeling tog baie duidelik nie eenwording, vereniging van twee kerke tot een nuwe kerk nie. Die bedoeling is dan dat die een moet ophou bestaan en opgaan in die ander. Solank dit so is, is alle pogings tot groter kerkeenheid gedoem tot mislukking.

\section{DIE VOLGENDE EEU}

Die gesprek tussen die Afrikaanse kerke moet voortgaan. Die huidige gesprek berus alreeds op 'n baie gesonder grondslag as 'n eeu gelede. 'n Paar dinge moet baie duidelik voor oë gehou word.

- Dit moet 'n eerlike, kerk-teologiese gesprek bly. Bymotiewe moet laat vaar word. Elke kerk moet hom eerlik afvra wat hy met kerkvereniging wil bereik. Gaan dit om gehoorsaamheid aan die Bybelse opdrag of is dit net om die ander een uit die pad te kry? Daarby moet begrip bestaan vir die moeilike weg wat na groter kerkeenheid voorlê. Honderd jaar se geskiedenis word nie oornag uit die weg geruim nie.

- Arrogansie en kerkisme moet afgesterf word. Ons moet in die gees van Christus na mekaar toe groei. Dan kan formele kerkvereniging uiteindelik 'n logiese, spontane uitvloeisel wees van 'n wesenlike eenheid wat reeds bestaan. Alleen so kan dit slaag en tot eer van God wees.

- Bybelse uitsprake oor eenheid moenie geïsoleerd en uit verband gebruik word nie. Die Bybel laat ook ruimte vir 'n gesonde, ryk 
verskeidenheid wat met sonde en verdeeldheid niks te make het nie. Dié aspek het nog nie genoeg aandag gekry nie.

- In die Nederduitsch Hervormde Kerk is dinge soos kanselruil 'n normale en ontspanne praktyk. Maar waarom kom dit selde of nooit van die anderkant af nie? Hoe praat 'n mens oor kerkeenheid of hoe wil jy verenig met 'n kerk wie se predikante jy nie op jou kansel toelaat nie? Ons moet ook in hierdie opsig van ons geloofslewe meer die daad by die woord voeg en begin doen wat ons preek. 